\title{
PENGARUH MOTIVASI DAN ETOS KERJA TERHADAP KINERJA PEGAWAI PADA BADAN NARKOTIKA NASIONAL KOTA PEMATANGSIANTAR
}

\author{
Oleh: \\ Dini Damanik \\ S1 Manajemen \\ Darwin Lie, Marisi Butarbutar, Fitria Halim
}

Abstraksi

Adapun rumusan masalah penelitian ini adalah bagaimana pengaruh motivasi dan etos kerja terhadap kinerja pegawai pada Badan Narkotika Nasional Kota Pematangsiantar. Desain penelitian yang digunakan dalam penulisan ini adalah penelitian kepustakaan dan penelitian lapangan. Populasi pada penelitian ini adalah seluruh pegawai Badan Narkotika Nasional Kota Pematangsiantar yang berjumlah 27 orang. Mengingat jumlah responden kurang dari 100 orang untuk menjawab kuesioner yang penulis sebarkan dan ketersediaan waktu penulis serta untuk keakuratan hasil penelitian. Jenis data yang digunakan adalah data kualitatif dan data kuantitatif. Teknik pengumpulan data dilakukan dengan kuesioner, wawancara dan dokumentasi. Teknik analisis data menggunakan analisis deskriptif kualitatif dan analisis deskriptif kuantitatif.

Hasil analisis dari regresi linier berganda yaitu $\hat{\mathrm{Y}}=6,518+0,827 \mathrm{X}_{1}+0,314 \mathrm{X}_{2}$ artinya terdapat pengaruh yang positif antara motivasi dan etos kerja terhadap kinerja pegawai. Kekuatan hubungan ketiga variabel adalah kuat, yaitu $r=0,791$. Dari koefisien determinasi dapat dijelaskan baik tidaknya kinerja pegawai sebesar $62,5 \%$ dapat dijelaskan oleh motivasi dan etos kerja, sedangkan sisanya 37,5\% dijelaskan oleh faktor lainnya yang tidak dibahas dalam penelitian ini. Dari hasil pengolahan data dan perhitungan kuesioner, penulis mendapatkan kesimpulan bahwa motivasi dan etos kerja yang diterapkan Badan Narkotika Nasional Kota Pematangsiantar berpengaruh positif dan signifikan terhadap kinerja pegawai. Hal ini dibuktikan melalui uji hipotesis secara simultan, dimana hasil uji $f_{\text {hitung }}(20,020)>t_{\text {tabel }}(3,40)$ dengan taraf signifikansi $0,000<$ alpha 0,05 .

Kata Kunci: Motivasi, Etos Kerja, Kinerja Pegawai

Abstraction

As for this research problem formula is how to influence Motivation and work ethic to employee performance at Badan Narkotika Nasional Kota Pematangsiantar. Design of this research was done by using the design of library research and field research. The population used in this research is all employees at Badan Narkotika Nasional Kota Pematangsiantar which amounted to 27 employees. Considering responder amount less than 100 people to reply the questionnaires which writer propagate and availibility of writer time and also for the accuracy of result of research. Types of data used are qualitative and quantitative data. Technique of data collected by questionnaires, interview and documentation. The analysis technique used is descriptive qualitative analysis and descriptive quantitative analysis.

The result of analysis from linear regression modestly that is $\hat{Y}=6,518+0,827 X_{1}+0,314 X_{2}$, it means there is a positive influence between motivation and work ethic to employee performance at Badan Narkotika Nasional Kota Pematangsiantar. The strength of relationship between the is high correlation, that is $r=0,791$. From coefficient determination can be explained that the level of employee performance can be explained by motivation and work ethic as big as $62,5 \%$, and the rest $37,5 \%$ can be explained by the other factor that was not discussed in this research. From result of processing and calculation questionnaires, writer get the conclusion that motivation and work ethic applied by Badan Narkotika Nasional Kota Pematangsiantar have an effect to employee performance. This matter is proved by hypothesis test either simultaneously where the result test $f_{\text {hitung }}$ $(20,020)>t_{\text {tabel }}(3,40)$ and which significant $0,000<$ alpha 0,05 .

Keywords: Motivation, Work Ethic, Employee Performance

\section{A. PENDAHUluan}

\section{Latar Belakang Masalah}

Badan Narkotika Nasional Kota Pematangsiantar merupakan sebuah organisasi yang bergerak di bawah naungan Pemerintahan yang dibentuk atas kerja sama Badan Narkotika Nasional dengan Pemerintah Daerah Kota Pematangsiantar dengan tugas melaksanakan pencegahan, pemberantasan, penyalahgunaan dan peredaran gelap narkotika, psikotropika dan bahan adiktif lainnya (P4GN) di daerah Kota Pematangsiantar.
Kinerja merupakan hasil kerja yang dicapai oleh seorang pegawai dalam melaksanakan tugas dan tanggung jawabnya. Menurut Peraturan Pemerintah Nomor 46 Tahun 2011, kinerja pegawai dapat diukur melalui dua dimensi, yaitu dimensi Sasaran Kerja Pegawai (SKP) meliputi unsur kualitas, kuantitas, biaya dan waktu, dan dimensi Perilaku Kerja (PK) meliputi unsur orientasi pelayanan, integritas, komitmen, disiplin, kerjasama dan kepemimpinan.

Motivasi merupakan dorongan yang mempengaruhi dan mengarahkan individu untuk melakukan kegiatan mencapai keberhasilan tujuan 
organisasi. Dalam hal ini motivasi terdiri dari tiga dimensi, yaitu kebutuhan akan prestasi merupakan sebagai suatu kesatuan watak yang memotivasi seseorang menghadapi tantangan. Kebutuhan akan afiliasi, merupakan kebutuhan manusia membentuk hubungan dan memiliki kaitan dan diterima oleh lingkungannya. Kebutuhan akan kekuasaan merupakan kebutuhan yang membuat orang lain berperilaku dalam suatu cara dimana orang-orang itu tanpa dipaksa.

Faktor lain yang dapat mempengaruhi kinerja pegawai adalah etos kerja. Etos kerja merupakan seperangkat perilaku positif yang berakar pada keyakinan fundamental yang disertai komitmen total pada paradigma kerja yang integral. Adapun dimensi etos kerja yaitu, kerja adalah rahmat dimana pegawai mau bekerja dengan tulus. Kerja adalah amanah seorang pegawai yang memiliki penuh tanggungjawab. Kerja adalah panggilan seseorang yang bekerja dengan tuntas. Kerja adalah aktualisasi merupakan sesorang penuh semangat. Kerja adalah ibadah pegawai yang bekerja serius dan penuh kecintaan. Kerja adalah seni dimana seseorang akan bekerja keras dan penuh kreativitas. Kerja adalah kehormatan seseorang akan bekerja tekun dan penuh keunggulan. Kerja adalah pelayanan dimana seseorang akan berkerja paripurna dan penbuh kerendahan hati.

\section{Rumusan Masalah}

a. Bagaimana gambaran motivasi, etos kerja dan kinerja pegawai pada Badan Narkotika Nasional Kota Pematangsiantar.

b. Bagaimana pengaruh motivasi dan etos kerja terhadap kinerja pegawai pada Badan Narkotika Nasional Kota Pematangsiantar baik secara simultan maupun parsial.

\section{Tujuan Penelitian}

a. Untuk mengetahui gambaran motivasi, etos kerja dan kinerja pegawai pada Badan Narkotika Nasional Kota Pematangsiantar.

b. Untuk mengetahui pengaruh motivasi dan etos kerja terhadap kinerja pegawai pada Badan Narkotika Nasional Kota Pematangsiantar baik secara simultan maupun parsial.

\section{Metode Penelitian}

Lokasi atau tempat penelitian ini dilakukan di Badan Narkotika Nasional Kota Pematangsiantar yang berada di Jalan Keselamatan, Kelurahan Suka Dame Kecamatan Siantar Utara.Telp. (0622) $5891080 \quad$ Fax: (0622) $5891880 \quad$ Kota Pematangsiantar, Sumatera Utara. Pada penelitian ini yang menjadi populasi adalah pegawai Badan Narkotika Nasional Kota Pematangsiantar sebanyak 27 pegawai. Seluruh pegawai yang berjumlah 27 orang akan menjadi sampel sebagai responden untuk menjawab kuesioner yang penulis sebarkan, mengingat jumlahnya kurang dari 100 (seratus) orang dan ketersediaan waktu penulis serta untuk keakuratan hasil penelitian.

Adapun desain penelitian yang digunakan dalam penulisan skripsi ini adalah Penelitian Kepustakaan (Library Research) dan Penelitian Lapangan (Field Research). Teknik pengumpulan data yang dilakukan penulis dalam penelitian ini adalah berupa Kuesioner, Wawancara dan Dokumentasi. Adapun jenis data yang digunakan dalam penelitian ini adalah jenis data kualitatif dan data kuantitatif. Hasil data yang diperoleh dari lapangan akan dianalisis secara deskriptif baik bersifat kualitatif dan kuantitatif.

\section{B. LANDASAN TEORI}

\section{Manajemen}

Manajemen merupakan sebuah seni menyelesaikan pekerjaan melalui bantuan orang lain. Menurut Daft (2002:8), manajemen adalah pencapaian sasaran-sasaran organisasi dengan cara yang efektif melalui perencanaan, pengorganisasian, kepemimpinan, dan pengendalian sumber daya organisasi. Menurut Handoko (2002:8), manajemen adalah proses perencanaan, pengorganisasian, pengarahan dan pengawasan usaha-usaha para anggota organisasi dan penggunaan sumber daya organisasi lainnya agar mencapai tujuan organisasi yang telah ditetapkan.

Sedangkan menurut Griffin (2004:8), manajemen adalah suatu rangkaian aktivitas (termasuk perencanaan dan pengambilan keputusan, pengorganisasian, kepemimpinan dan pengendalian) yang diarahkan pada sumber-sumber daya organisasi (manusia, finansial, fisik dan informasi) untuk mencapai tujuan organisasi dengan cara yang efektif dan efisien. Berdasarkan pendapat para ahli yang telah diuraikan, dapat disimpulkan bahwa manajemen merupakan suatu ilmu atau seni yang digunakan untuk mengatur dan mengarahkan orang lain dengan maksud untuk mencapai tujuan organisasi secara efektif dan efisien.

Menurut Daft (2002:8), fungsi dari manajemen adalah sebagai berikut:

a. Perencanaan (Planning)

Fungsi manajemen yang berhubungan dengan penentuan tujuan ingin diraih oleh organisasi dan penetapan tugas-tugas dan alokasi sumber daya untuk mencapai tujuan tersebut.

b. Pengorganisasian (Organizing)

Fungsi manajemen yang berkaitan dengan penetapan dan pengelompokan tugas-tugas ke dalam departemen dan pengalokasian sumber daya ke berbagai departemen.

c. Kepemimpinan (Leading)

Fungsi manajemen yang melibatkan penggunaan pengaruh untuk memotivasi karyawan meraih sasaran organisasi.

d. Pengendalian (Controlling)

Fungsi manajemen yang berhubungan dengan pemantauan aktivitas-aktivitas karyawan, menjaga organisasi agar tetap berjalan kearah pencapaian sasaran-sasarannya, dan membuat koreksi jika diperlukan. 


\section{Manajemen Sumber Daya Manusia}

Manajemen sumber daya manusia merupakan suatu alternatif atau cara yang digunakan untuk mengatur segala kegiatan yang berhubungan dengan sumber daya manusia. Menurut Mondy (2008:4), manajemen sumber daya manusia adalah pemanfaatan sejumlah individu untuk mencapai tujuan-tujuan organisasi. Menurut Mathis dan John (2006:3), manajemen sumber daya manusia adalah rancangan sistem-sistem formal dalam sebuah organisasi untuk memastikan penggunaan bakat manusia secara efektif dan efisien guna mencapai tujuan-tujuan organisasional.

Sedangkan menurut Bangun (2012:6), manajemen sumber daya manusia didefinisikan sebagai suatu proses perencanaan, pengorganisasian, penyusunan staf, penggerakan dan pengawasan terhadap pengadaan, pengembangan, pemberian kompensasi, pengintegrasian, pemeliharaan, dan pemisahan tenaga kerja untuk mencapai tujuan organisasi. Berdasarkan uraian pendapat para ahli, maka dapat disimpulkan bahwa manajemen sumber daya manusia adalah suatu cara yang digunakan oleh organisasi dengan memanfaatkan pengetahuan dan bakat individu untuk mencapai tujuan organisasi.

Menurut Mondy (2008:4), fungsi manajemen sumber daya manusia adalah sebagai berikut:

a. Penyediaan Staf

Yaitu proses yang menjamin suatu organisasi untuk selalu memiliki jumlah karyawan yang tepat dengan keahlian-keahlian yang memadai dalam pekerjaan-pekerjaan yang tepat pada waktunya untuk mencapai tujuan organisasi.

b. Pengembangan Sumber Daya Manusia

Fungsi manajemen sumber daya manusia yang tidak hanya terdiri atas pelatihan dan pengembangan, namun juga aktivitas-aktivitas perencanaan dan pengembangan karir individu, pengembangan organisasi, serta manajemen dan penilaian kinerja.

c. Kompensasi

Yaitu suatu sistem yang terencana matang memberi para karyawan imbalan-imbalan yang layak dan adil atas kontribusi mereka dalam mencapai tujuan-tujuan organisasi. Ada tiga macam kompensasi, antara lain kompensasi finansial langsung, kompensasi finansial tidak langsung, dan kompensasi non finansial.

d. Keselamatan dan Kesehatan

Keselamatan adalah perlindungan bagi para karyawan yang disebabkan kecelakaankecelakaan yang terkait dengan pekerjaan. Kesehatan adalah bebasnya para karyawan dari sakit secara fisik atau emosi.

e. Hubungan Kekaryawanan dan Perburuhan Hubungan karyawan dengan pihak perusahaan haruslah dijaga dengan baik, agar karyawan lebih termotivasi untuk mencapai tujuan perusahaan yang telah ditetapkan.

\section{Motivasi}

Motivasi merupakan suatu proses psikologis yang mencerminkan antar sikap, kebutuhan, persepsi, dan kebutuhan yang terjadi pada diri seseorang. Menurut Handoko (2002:252), motivasi diartikan sebagai keadaan dalam pribadi seseorang yang mendorong keinginan individu untuk melakukan-melakukan kegiatan tertentu guna mencapai tujuan. Menurut Luthans (2006:270), motivasi adalah keadaan dalam diri individu yang memunculkan, mengarahkan, dan mempertahakan perilaku. Dengan kata lain motivasi berarti dorongan terhadap seseorang agar mau melaksanakan sesuatu. Dengan adanya dorongan ini maka desakan alami untuk memuaskan kebutuhan-kebutuhan hidup dan juga merupakn kecenderungan mempertahankan hidup. Sedangkan Menurut Robbins dan Timothy (2006:222), motivasi adalah usaha mencapai tujuan apapun, bila dipersempit menjadi tujuan-tujuan organisasi untuk mencerminkan minat kita terhadap perilaku yang berhubungan dengan pekerjaan, jadi motivasi berpengaruh terhadap kinerja.

Hal-hal yang memotivasi seseorang adalah:

1) Kebutuhan akan prestasi (Need for Achievement

Kebutuhan akan prestasi merupakan daya penggerak yang memotivasi semangat bekerja seseorang. Karena itu kebutuhan akan prestasi akan mendorong seseorang untuk mengembangkan kreativitas dan mengarahkan semua kemampuan serta sinergi yang dimilikinya demi mencapai prestasi kerja yang maksimal.

2) Kebutuhan akan afiliasi (Need for Affiliation) Kebutuhan akan afiliasi daya penggerak yang akan memotivasi semangat kerja seseorang. Oleh karena itu, kebutuhan akan afiliasi yang merangsang gairah bekerja pegawai karena setiap orang menginginkan hal-hal berikut:

(a) Kebutuhan akan perasaan diterima oleh orang lain di lingkungan ia tinggal dan bekerja (sense of belonging)

(b) Kebutuhan akan perasaan dihormati, karena setiap manusia merasa dirinya penting (sence of importance)

(c) Kebutuhan akan maju dan tidak gagal (sence of achievement)

(d) Kebutuhan akan perasaan ikut serta (sence of participation)

Seseorang karena kebutuhan akan afiliasi akan memotivasi dan mengembangkan dirinya serta memanfaatkan semua energinya untyk menyelesaikan tugas-tugasnya, jadi seseorang termotivasi oleh kebutuhan akan afiliasi ini.

3) Kebutuhan akan kekuasaan (Need for Power) Kebutuhan akan kekuasaan merupakan daya penggerak yang memotivasi semangat kerja karyawan. Kebutuhan akan kekuasaan akan merangsang dan memotivasi gairah karyawan serta mengarahkan semua kemampuannya demi mencapai kekuasaan atau kedudukan yang terbaik. Ego manusia ingin lebih berkuasa dari manusia lainnya akan menimbulkan persaingan. Persaingan ditumbuhkan secara sehat oleh manajer dalam memotivasi bawahannya, supaya mereka termotivasi untuk giat bekerja. 


\section{Etos Kerja}

Menurut Sinamo (2005:282), menyatakan bahwa etos kerja adalah seperangkat perilaku positif yang berakar pada keyakinan fundamental yang disertai komitmen total paradigma kerja yang integral. Menurutnya, jika seseorang, suatu organisasi, atau suatu komunitas menganut paradigma kerja, mempercayai, dan komitmen paradigma kerja tersebut, semua itu akan melahirkan sikap dan perilaku kerja mereka yang khas. Itulah yang menjadi budaya kerja. Sedangkan menurut Anoraga (2009:282), menyatakan bahwa etos kerja merupakan suatu pandangan dan sikap suatu bangsa atau umat terhadap kerja. Bila individu-individu dalam komunitas memandang kerja sebagai suatu hal luhur bagi eksistensi manusia, maka etos kerjanya akan cenderung tinggi. Sebaliknya sikap dan pandangan terhadap kerja sebagai sesuatu yang bernilai rendah bagi kehidupan, maka etos kerja dengan sendirinya akan rendah. Cherrington (2000:283), menyatakan bahwa etos kerja mengarah kepada sikap positif pegawai terhadap pekerjaan yang diembannya. Ini berarti bahwa pegawai yang menikmati pekerjaanya memiliki etos kerja yang lebih besar dari pada pegawai yang tidak menikmati pekerjaannya. Berdasarkan berbagai pendapat ahli tersebut, dapat disimpulkan bahwa etos kerja merupakan suatu pandangan dan sikap pada keyakinan fundamental yang disertai komitmen yang positif bagi peningkatan kualitas kehidupan, sehingga mempengaruhi perilaku kerjanya dalam suatu organisasi.

Menurut Sinamo (2005:232), pada delapan aspek etos kerja sebagai berikut:

1) Kerja adalah rahmat, sehingga seseorang mau bekerja dengan tulus dan penuh syukur.

2) Kerja adalah amanah, sehingga seseorang memiliki komitmen untuk bekerja benar dan penuh tanggung jawab.

3) Kerja adalah panggilan, sehingga seseorang bisa bekerja tuntas dan penuh tanggung jawab.

4) Kerja adalah aktualisasi, maka seseorang harus bekerja keras dan penuh semangat.

5) Kerja adalah ibadah, sehingga seseorang memiliki komitmen untuk bekerja dengan serius dan penuh kecintaan.

6) Kerja adalah seni, sehingga seseorang akan bekerja cerdas dan penuh kreativitas.

7) Kerja adalah kehormatan, sehingga seseorang akan bekerja akan bekerja tekun dan penuh keunggulan.

8) Kerja adalah pelayanan, sehingga seseorang akan bekerja paripurna dan penuh kerendahan hati.

\section{Kinerja}

Salah satu kunci keberhasilan sebuah organisasi atau perusahaan adalah terletak pada kinerja sumber daya manusia yang dihasilkan. Menurut Mangkunegara (2005:9), kinerja didefinisikan sebagai hasil kerja secara kualitas dan kuantitas yang dikejar oleh seorang karyawan dalam melaksanakan tugas dan fungsinya sesuai dengan tanggung jawab yang diberikan kepadanya. Sedangkan menurut Rivai (2004:309), kinerja dikatakan berupa perilaku yang nyata yang ditunjukkan oleh setiap orang sebagai prestasi kerja yang dihasilkan oleh karyawan sesuai dengan perannya dalam perusahaan. Lalu menurut Mathis dan John (2006:113), kinerja adalah suatu hasil kerja yang dicapai seseorang dalam melaksanakan tugastugas yang dibebankan kepadanya yang disarankan atas pengalaman, kesungguhan, kecakapan serta waktu.

Berdasarkan uraian di atas, maka dapat disimpulkan bahwa kinerja adalah hasil kerja yang dicapai oleh seseorang dalam periode tertentu yang dilaksanakan untuk memenuhi tugas dan tanggung jawab yang telah dibebankan kepadanya guna mencapai tujuan organisasi.

Menurut Mathis dan John (2006:378), ada tiga faktor utama yang mempengaruhi kinerja pegawai, yaitu:

a. Kemampuan Individual, mencakup bakat, minat, dan faktor kepribadian. Tingkat keterampilan merupakan bahan mentah yang dimiliki seorang pegawai berupa pengetahuan, pemahaman, kemampuan, interpersonal, dan kecakapan teknis.

b. Usaha yang Dicurahkan adalah etika kerja, kehadiran, dan motivasi. Tingkat usaha merupakan gambaran motivasi yang diperlihatkan pegawai untuk menyelesaikan pekerjaan dengan baik. Tingkat keterampilan merupakan cermin dari apa yang dilakukan.

c. Dukungan Organisasional, perusahaan menyediakan fasilitas bagi pegawai dasar dari apa yang dilakukan atau tidak dilakukan pegawai. Kinerja pegawai adalah apa yang mempengaruhi sebanyak mereka memberikan kontribusi bagi organisasi.

Presiden Republik Indonesia telah menetapkan peraturan mengenai Sasaran Kerja Pegawai (SKP) yaitu Peraturan Pemerintah Republik Indonesia Nomor 46 Tahun 2011 Tentang Penilaian Prestasi Kerja Pegawai Negeri Sipil. Dalam pasal 1 ayat 2 Peraturan Pemerintah No. 46 Tahun 2011 tentang Penilaian Prestasi Kerja Pegawai Negeri Sipil, secara umum dibagi dalam 2 (dua) unsur, yaitu:

a. Sasaran Kerja Pegawai (SKP)

Sasaran Kerja Pegawai (SKP) adalah rencana kerja dan target yang dicapai oleh seorang PNS dan dikerjakan berdasarkan kurun waktu tertentu. Sasaran Kerja Pegawai melihat beberapa unsur sebagai berikut:

1) Kuantitas, berupa ukuran jumlah atau banyaknya hasil kerja yang dicapai oleh seorang karyawan.

2) Kualitas, berupa ukuran mutu setiap hasil kerja yang dicapai oleh seorang karyawan.

3) Waktu, berupa ukuran lamanya proses setiap hasil kerja yang dicapai oleh seorang karyawan. 
4) Biaya, berupa besaran jumlah anggaran yang digunakan setiap hasil kerja oleh seorang pegawai.

b. Perilaku Kerja (PK)

Perilaku kerja merupakan setiap tingkah laku, sikap atau tindakan yang dilakukan seorang Pegawai Negeri Sipil (PNS) yang seharusnya dilakukan sesuai dengan ketentuan dalam peraturan perundangundangan yang berlaku. Adapun unsur-unsur perilaku kerja terdiri dari:

1) Orientasi Pelayanan, berupa sikap dan tingkah laku PNS dalam memberikan pelayanan terbaik kepada orang yang dilayani antara lain: masyarakat, atasan, rekan sekerja, unit kerja terkait, dan instansi lain.

2) Integritas, merupakan kemampuan untuk bertindak sesuai dengan nilai, norma, dan etika dalam organisasi.

3) Komitmen, merupakan kemauan dan kemampuan untuk menyelaraskan sikap dan tindakan PNS untuk mewujudkan tujuan organisasi dan mengutamakan kepentingan diri sendiri, seseorang dan golongan.

4) Disiplin, merupakan kesanggupan PNS untuk menaati kewajiban dan menghindari larangan yang ditentukan dalam peraturan perundangundangan dan peraturan kedinasan yang apabila tidak ditaati atau dilanggar dijatuhi hukuman disiplin.

5) Kerjasama, merupakan kemauan dan kemampuan PNS untuk bekerjasama dengan rekankerja serta instansi lain dalam menyelesaikan suatu tugas dan tanggungjawab yang ditentukan sehingga tercapai daya guna dan hasil guna yang sebesar-besarnya.

6) Kepemimpinan, merupakan kemampuan dan kemauan PNS untuk memotivasi dan mempengaruhi bawahan atau orang lain yang berkaitan dengan bidang tugasnya demi tercapainya tujuan organisasi.

\section{Pengaruh Motivasi dan Etos Kerja Terhadap Kinerja Pegawai}

Motivasi merupakan suatu hal yang dapat meningkatkan hasil kerja seseorang. Dengan diberikannya motivasi maka pegawai yang bekerja pada perusahaan tersebut dapat berguna dan juga membantu perusahaan untuk mencapai tujuan yang telah ditetapkannya. Menurut Mangkunegara (2015:67), faktor-faktor yang mempengaruhi kinerja seseorang yaitu faktor kemampuan dan motivasi. Motivasi berasal dari sikap karyawan dalam menghadapi situasi kerja. Dengan diberikan motivasi, maka karyawan yang bekerja pada perusahaan tersebut dapat berguna juga membantu perusahaan untuk mencapai tujuan yang telah ditetapkan. Motivasi dapat dipastikan mempengaruhi kinerja. Hal ini dapat dijelaskan dari model hubungan antara motivasi dan kinerja.

Etos kerja yang dimiliki oleh seorang pegawai dan dengan sesuai dengan tuntutan pekerjaan, maka kinerja pegawai akan semakin meningkat karena pegawai yang berkompeten biasanya memiliki kemampuan yang cepat untuk mengatasi permasalahan kerja yang dihadapi, melakukan pekerjaan dengan penuh dedikasi, tenang dan penuh rasa percaya diri, memandang pekerjaan sebagai kewajiban yang harus dilakukan secara ikhlas, dan secara terbuka meningkatkan kualitas diri melalui proses pembelajaran.

Menurut Cherrington (2000:283), etos kerja mengarah pada sikap positif pegawai tehadap pekerjaan yang diembannya. Ini berarti bahwa pegawai yang memiliki etos kerja yang tinggi akan tercermin dalam prilakunya, seperti suka bekerja keras, bersikap adil, tidak membuang-buang waktu selama jam kerja, mau bekerjasama, hormat terhadap rekan-rekan dan sebagainya.

\section{PEMBAHASAN}

\section{Analisis}

\section{a. Deskriptif Kualitatif}

Analisis deskriptif dimaksudkan untuk mendapatkan gambaran atau deskripsi mengenai tanggapan dari pegawai mengenai pengaruh motivasi dan etos kerja terhadap kinerja pegawai pada Badan Narkotika Nasional Kota Pematangsiantar. Setelah pengujian data, maka langkah selanjutnya adalah peneliti melakukan pengkajian analisis kualitatif sebagai gambaran fenomena dari variabel penelitian pada saat sekarang ini. Adapun penetapan kriteria nilai data-data jawaban dari responden tersebut dimasukkan ke dalam kelas-kelas interval, dimana penentuan intervalnya menggunakan rumus sebagai berikut:

$$
\begin{gathered}
\text { Interval Kelas }=\frac{\text { Nilai Tertinggi }- \text { Nilai Terendah }}{} \\
=\frac{5-1}{5} \\
=\frac{4}{5} \\
=0,8
\end{gathered}
$$

Dari rumus di atas, diperoleh nilai interval kelas $=0,8$, sehingga berlaku ketentuan kategori dengan hasil sebagai berikut:

Tabel 1

Nilai Interval dan Kategori Jawaban Responden.

\begin{tabular}{|c|c|}
\hline $\begin{array}{c}\text { Nilai } \\
\text { Interval }\end{array}$ & Kategori \\
\hline $1,00-1,80$ & Sangat Tidak Baik (STB) \\
\hline $1,81-2,60$ & Tidak Baik (TB) \\
\hline $2,61-3,40$ & Cukup Baik (CB) \\
\hline $3,41-4,20$ & Baik (B) \\
\hline $4,21-5,00$ & Sangat Baik (SB) \\
\hline
\end{tabular}

Sumber: hasil pengolahan data

\section{1) Gambaran Motivasi pada Badan Narkotika Nasional Kota Pematangsiantar}

Motivasi merupakan dorongan yang mempengaruhi dan mengarahkan pegawai untuk melakukan kegiatan tertentu guna mencapai tujuan yang dicapai. Semakin besar motivasi yang diberikan kepada pegawai tersebut maka semakin tinggi tingkat kepuasan kerjanya. Penerapan motivasi yang 
ada pada Badan Narkotika Nasional Kota Pematangsiantar dilakukan dengan cara menempatkan pegawai pada bidang pekerjaan yang sesuai dengan kemampuan dan keahlian yang dimiliki. Adapun dimensi motivasi yang terdapat pada Badan Narkotika Nasional Kota Pematangsiantar meliputi kebutuhan akan prestasi, yaitu mendorong seseorang untuk mengembangkan kreativitas dan mengarahkan semua kemampuan serta energy yang dimilikinya demi mencapai prestasi kerja yang maksimal, penerapan yang dilakukan seperti memberikan kebebasan untuk dapat memperoleh pengetahuan guna keberhasilan prestasi kerja yang maksimal.

Kebutuhan akan afiliasi, yaitu kebutuhan akan perasaan diterima oleh orang lain, dan dihargai atas prestasi kerja, dalam hal ini Badan Narkotika Nasional Kota Pematangsiantar untuk dapat menerapkannya memberikan apresiasi atau penghargaan kepada karyawan atas keberhasilan pekerjaan yang dilakukan, dan kebutuhan akan kekuasaan yaitu kebutuhan akan suatu jabatan, penerapan yang dilakukan seperti memberikan kesempatan promosi jabatan agar mendorong semangat kerja karyawan.

Secara keseluruhan dapat dilihat bahwa untuk total jawaban responden mengenai motivasi berada pada rata-rata 3,84dengan kriteria jawaban baik. Nilai rata-rata tertinggi sebesar 4,22 dengan kriteria jawaban sangat baik pada dimensi kebutuhan akan kekuasaan dengan indikator usaha dalam mengikuti perkembangan IPTEK dalam menghadapi persaingan untuk meraih jabatan tertentu. Sedangkan nilai rata-rata terendah sebesar 3,22 dengan kriteria jawaban cukup baik pada dimensi kebutuhan akan prestasi tentang usaha dalam mencari pengetahuan untuk mencapai prestasi kerja yang maksimal.

\section{2) Gambaran Etos Kerja pada Badan Narkotika Nasional Kota Pematangsiantar}

Etos kerja merupakan suatu pandangan dan sikap pada keyakinan fundamental yang disertai komitmen yang positif bagi peningkatan kualitas kehidupan, sehingga mempengaruhi perilaku kerjanya dalam suatu organisasi Di suatu organisasi perilaku positif seorang pegawai terhadap organisasi sangat diperlukan untuk menunjang tercapainya tujuan dari organisasi.

Etos kerja merupakan suatu pandangan dan sikap pada keyakinan fundamental yang disertai komitmen yang positif bagi peningkatan kualitas kehidupan, sehingga mempengaruhi perilaku kerjanya dalam suatu organisasi Di suatu organisasi perilaku positif seorang pegawai terhadap organisasi sangat diperlukan untuk menunjang tercapainya tujuan dari organisasi. Dalam hal ini, Badan Narkotika Nasional Kota Pematangsiantar membangun etos kerja yang baik kepada pegawainya sebagai prasyarat yang mutlak yang harus ditumbuhkan dalam kehidupan setiap pegawai. Karena hal ini akan membuka pandangan dan sikap terhadap untuk menilai baik terhadap kerja keras dan sungguh-sungguh, sehingga dapat mengikis setiap kerja yang asal-asalan. Adapun dimensi etos kerja pada Badan Narkotika Nasional Kota Pematangsiantar diantaranya kerja adalah rahmat, kerja adalah amanah, kerja adalah panggilan, kerja adalah aktualisasi, kerja adalah ibadah, kerja adalh seni, kerja adalah kehormatan dan kerja adalah pelayanan.

3) Gambaran Kinerja Pegawai pada Badan Narkotika Nasional Kota Pematangsiantar

Kinerja merupakan hasil kerja yang dicapai oleh seseorang dalam melaksanakan tugas-tugas yang dibebankan kepadanya sesuai dengan kemampuan dan keterampilan yang dimiliki. Dengan demikian kinerja merupakan sesuatu yang penting untuk selalu ditingkatkan oleh pegawai sehingga dapat membantu organisasi dalam mewujudkan tujuannya. Kinerja pegawai pada Badan Narkotika Nasional Kota Pematangsiantar dinilai berdasarkan Peraturan Pemerintah Republik Indonesia Nomor 46 Tahun 2011 Tentang Penilaian Prestasi Kerja Pegawai Negeri Sipil. Penilaian prestasi kerja tersebut terdiri dari dua unsur yaitu Sasaran Kerja Pegawai (SKP) dan Perilaku Kerja (PK).

Dimensi sasaran kerja pegawai pada Badan Narkotika Nasional Kota Pematangsiantar diantaranya kuantitas, dapat dilihat ketika pegawai mampu menyelesaikan pekerjaan sesuai dengan target yang telah ditentukan. Kualitas dapat dilihat ketika pegawai mampu melaksanakan pekerjaan dengan penuh ketelitian sehingga memperoleh hasil yang sesuai. Waktu dapat dilihat ketika pegawai mampu memanfaatkan waktu kerja sebaik mungkin sehingga pekerjaan dapat terselesaikan dengan tepat waktu. Biaya dapat dilihat ketika pegawai mampu mengalokasikan anggaran yang diberikan dengan baik.

Dimensi perilaku kerja pada Badan Narkotika Nasional Kota Pematangsiantar meliputi orientasi pelayanan, dapat dilihat ketika pegawai dapat memberikan pelayanan yang baik dan ramah kepada masyarakat. Integritas dapat dilihat ketika pegawai mampu bersikap sopan dan jujur sesuai dengan norma dan etika dalam instansi. Komitmen dapat dilihat ketika pegawai bersedia mengabdikan dirinya pada instansi dan secara bersama-sama dalam mewujudkan tujuan dari instansi. Disiplin dapat dilihat ketika pegawai mampu mematuhi peraturan yang berlaku, seperti datang tepat waktu dan tidak menggunakan jam istirahat secara berlebih. Kerjasama dapat dilihat ketika pegawai saling bekerjasama dan saling terlibat dalam menyelesaikan suatu pekerjaan yang kurang dipahami. Kepemimpinan dapat dilihat ketika pimpinan mampu mengarahkan dan memotivasi bawahannya untuk bekerja semaksimal mungkin dalam rangka mencapai tujuan dari instansi.

Berdasarkan hasil analisis deskriptif kualitatif yang telah dilakukan, secara keseluruhan dapat dilihat bahwa untuk total jawaban responden mengenai kinerja pegawai memperoleh nilai rata-rata sebesar 3,90 dengan kriteria jawaban baik. Nilai ratarata tertinggi sebesar 4,30 dengan kriteria jawaban 
sangat baik pada dimensi perilaku kerja dengan indikator tanggung jawab pegawai dalam melaksanakan tugas yang diberikan. Sedangkan nilai rata-rata terendah sebesar 3,33 dengan kriteria jawaban cukup baik pada dimensi sasaran kerja pegawai dengan indikator tingkat efisiensi waktu yang dipergunakan dalam menyelesaikan pekerjaan.

\section{b. Deskriptif Kuantitatif}

\section{1) Analisis Regresi Linear Berganda}

Fungsi dari analisis regresi adalah untuk melihat pengaruh yang terjadi di antara ketiga variabel. Selain itu analisis regresi juga berfungsi sebagai penunjuk arah hubungan yang terjadi antara variabel dependen dan variabel indenpenden. Untuk melihat apakah ada pengaruh kompetensi dan komitmen terhadap kinerja pegawai pada Badan Narkotika Nasional Kota Pematangsiantar digunakan analisis regresi linear berganda.

Tabel 2

Analisis Regresi Linier Berganda

\begin{tabular}{|c|r|r|c|}
\hline \multirow{2}{*}{ Model } & \multicolumn{2}{|c|}{$\begin{array}{c}\text { Unstandardized } \\
\text { Coefficients }\end{array}$} & $\begin{array}{c}\text { Standardize } \\
\boldsymbol{d} \\
\text { Coefficients }\end{array}$ \\
\cline { 2 - 4 } & \multicolumn{1}{|c|}{$\boldsymbol{B}$} & \multicolumn{1}{c|}{$\begin{array}{c}\text { Std. } \\
\text { Error }\end{array}$} & Beta \\
\hline (Constant) & $\mathbf{6 . 5 1 8}$ & 11.486 & \\
1 Motivasi & $\mathbf{. 8 2 7}$ & .321 & .458 \\
Etos Kerja & & & .396 \\
\hline
\end{tabular}

a. Dependent Variabel: Kinerja Pegawai

Sumber: hasil pengolahan data menggunakan SPSS versi 21 (2017)

Berdasarkan hasil pengolahan data pada tabel $17 \mathrm{di}$ atas, diperoleh model persamaan $\hat{\mathrm{Y}}=$ $6,518+0,827 \mathrm{X}_{1}+0,314 \mathrm{X}_{2}$, artinya terdapat pengaruh yang positif antara motivasi dan etos kerja terhadap kinerja pegawai pada Badan Narkotika Nasional Kota Pematangsiantar.

\section{2) Koefisien Korelasi dan Koefisien Determinasi}

Untuk menghitung kekuatan hubungan motivasi, etos kerja dan kinerja pegawai, dilakukan melalui analisis koefisien korelasi dan koefisien determinasi dengan rumus sebagai berikut:

Tabel 3

Koefisien Korelasi dan Koefisien Determinasi

\begin{tabular}{|c|c|c|c|c|}
\hline $\begin{array}{c}\text { Mode } \\
\mathbf{l}\end{array}$ & $\mathbf{R}$ & $\begin{array}{c}\boldsymbol{R} \\
\text { Square }\end{array}$ & $\begin{array}{c}\text { Adjusted } \boldsymbol{R} \\
\text { Square }\end{array}$ & $\begin{array}{c}\text { Std. Error of } \\
\text { the Estimate }\end{array}$ \\
\hline 1 & $\mathbf{7 9 1}^{\mathrm{a}}$ & $\mathbf{. 6 2 5}$ & .594 & 4.4973 \\
\hline
\end{tabular}

a. Predictors: (Constant), Motivasi, Etos Kerja

b. Dependent Variabel: Kinerja Pegawai
Sumber: hasil pengolahan data menggunakan SPSS versi 21 (2017)

Berdasarkan hasil pengolahan data pada tabel 18 di atas, diperoleh nilai $r=0,791$ yang artinya terdapat hubungan yang sangat kuat dan positif antara motivasi dan etos kerja terhadap kinerja pegawai pada Badan Narkotika Nasional Kota Pematangsiantar, sesuai dengan kriteria koefisien korelasi pada tabel 5 .

Selanjutnya diperoleh nilai koefisien determinasi $(\mathrm{R}$ Square $)=0,625$, artinya baik tidaknya kinerja pegawai (Y) pada Badan Narkotika Nasional Kota Pematangsiantar sebesar 62,5\% dapat dijelaskan oleh motivasi $\left(\mathrm{X}_{1}\right)$ dan etos kerja $\left(\mathrm{X}_{2}\right)$, sedangkan sisanya sebesar $37,5 \%$ dipengaruhi oleh faktor lain seperti dukungan organisasi, dukungan manajemen, lingkungan kerja, budaya organisasi, efektivitas dan efisiensi serta disiplin.

\section{3) Uji Hipotesis}

a) Uji Simultan (Uji F)

Uji $\mathrm{F}$ digunakan untuk mengetahui apakah variabel bebas (motivasi dan etos kerja) berpengaruh terhadap variabel terikat (kinerja pegawai) secara bersama-sama atau simultan. Yaitu dilakukan untuk menentukan diterima atau ditolaknya hipotesis. Jika tingkat signifikan dibawah $5 \%$ atau $\mathrm{F}_{\text {hitung }}>\mathrm{F}_{\text {tabel }}$ maka $\mathrm{H}_{0}$ ditolak.

Tabel 4

Perkiraan Nilai F $F_{\text {hitung }}$

\begin{tabular}{|l|r|r|r|c|c|}
\hline Model & $\begin{array}{c}\text { Sum of } \\
\text { Squares }\end{array}$ & df & $\begin{array}{c}\text { Mean } \\
\text { Square }\end{array}$ & F & Sig. \\
\hline Regressio & 808.399 & 2 & 404.20 & $\mathbf{2 0 . 0 2}$ & $\mathbf{. 0 0 0}$ \\
$n$ & & & 0 & $\mathbf{0}$ & $\mathbf{b}$ \\
1 Residual & 484.564 & 2 & 20.190 & & \\
& & 4 & & & \\
Total & 1292.96 & 2 & & & \\
\hline
\end{tabular}

a. Dependent Variabel: Kinerja Pegawai

b. Predictors: (Constant), Motivasi, Etos Kerja

Sumber: hasil pengolahan data menggunakan SPSS versi 21 (2017)

Berdasarkan table 4 di atas diperoleh hasil $\mathrm{f}_{\text {hitung }}$ dengan $\mathrm{df}=\mathrm{n}-\mathrm{k}-1(27-2-1=24)$ sebesar 23,680, sedangkan $\mathrm{f}_{\text {tabel }}(0,05 ; 2$ vs 24$)$ sebesar 3,40 atau dengan signifikansi $0,000<\alpha 0,05$, maka $\mathrm{H}_{0}$ ditolak, artinya kompetensi dan komitmen berpengaruh positif dan signifikan terhadap kinerja pegawai pada Badan Narkotika Nasional Kota Pematangsiantar.

b) Uji Parsial (Uji t)

Untuk menghasilkan suatu kesimpulan yang valid, maka harus dilakukan uji hipotesis. Pengujian ini dilakukan untuk menentukan diterima atau ditolaknya hipotesis, pengujian hipotesis dilakukan untuk mengetahui apakah variabel kompetensi dan komitmen yang diuji berpengaruh terhadap kinerja pegawai. Jika tingkat signifikansi dibawah $5 \%$ atau $t_{\text {hitung }}>t_{\text {tabel }}$ maka $\mathrm{H}_{0}$ ditolak.

Tabel 5

Perkiraan Nilai thitung

\begin{tabular}{|l|c|c|} 
Model & T & Sig. \\
\hline
\end{tabular}




\begin{tabular}{|l|c|c|}
\hline (Constant) & .567 & .576 \\
1 Motivasi & $\mathbf{2 . 5 7 7}$ & $\mathbf{. 0 1 7}$ \\
Etos Kerja & $\mathbf{2 . 2 2 4}$ & $\mathbf{. 0 3 6}$ \\
\hline
\end{tabular}

a. Dependent Variabel: Kinerja Pegawai

Sumber: hasil pengolahan data menggunakan SPSS versi 21 (2017)

Dari tabel 5 di atas diperoleh nilai pada $t_{\text {hitung }}$ variabel $\mathrm{X}_{1}$ (motivasi) sebesar $2.577>\mathrm{t}_{\text {tabel }}$ dengan $\mathrm{df}$ $=\mathrm{n}-\mathrm{k}-1 \quad(27-2-1=24)$ sebesar 2,063 atau taraf signifikansi $0,020<$ alpha 0,05 , maka $\mathrm{H}_{0}$ ditolak, artinya motivasi berpengaruh positif dan signifikan terhadap kinerja pegawai pada Badan Narkotika Nasional Kota Pematangsiantar. Kemudian nilai $t_{\text {hitung }}$ pada variabel $\mathrm{X}_{2}$ (etos kerja) sebesar 2,224 > $t_{\text {tabel }}$ dengan $\mathrm{df}=\mathrm{n}-\mathrm{k}-1 \quad(27-2-1=24)$ sebesar 2,063 atau taraf signifikansi 0,036 < alpha 0,05 , maka $\mathrm{H}_{0}$ ditolak, artinya etos kerja berpengaruh positif dan signifikan terhadap kinerja pegawai pada Badan Narkotika Nasional Kota Pematangsiantar.

\section{Evaluasi}

\section{a. Motivasi Pada Badan Narkotika Nasional}

\section{Kota Pematangsiantar}

Motivasi yang baik akan berperan penting terhadap output dan input dari perusahaan tersebut, baik itu dari segi kualitas maupun kuantitasnya pasti akan baik dan para pegawai akan termotivasi untuk tidak pindah kerja, karena masa depan akan terjamin apabila para pegawai melihat perkembangan perusahaan saat ini. Pada Badan Narkotika Nasional Kota Pematangsiantar sendiri motivasi yang diberikan kepada pegawai seperti kebutuhan akan prestasi yaitu dengan memberikan kebebasan bagi pegawai untuk mencari pengetahuan agar mencapai prestasi kerja yang maksiml, kebutuhan akan afiliasi yaitu dengan memberikan tunjangan serta apresiasi lain yang bersifat penghargaan atas prestasi kerja pegawai, dan kebutuhan akan kekuasaan yaitu dengan memberikan promosi agar mendorong semangat kerja pegawai.

Motivasi pada Badan Narkotika Nasional Kota Pematangsiantar berdasarkan hasil penelitian dinilai baik. Dilihat dari hasil kuesioner yang dibagikan kepada responden mendapat nilai rata-rata 3,84 dengan kriteria jawaban baik. Namun ada beberapa aspek walaupun dinilai baik tetapi masih ada yang dinilai dibawah rata-rata dari indikatorindikator lain, pertama dimensi kebutuhan akan prestasi dengan indikator usaha yang dilakukan dalam mencari pengetahuan dapat mencari prestasi kerja yang maksimal memperoleh nilai 3,22 dengan kriteria baik. Untuk mengatasi sebaiknya para pegawai harus lebih meningkatkan pengetahuan yang lebih dalam lagi dalam membuat alternatife untuk menjalankan pekerjaannya. Dan kondisi kerja sama dengan sesama rekan kerja memperoleh nilai 3,66 dengan kriteia baik. Untuk mengoptimalkan para pegawai dapat saling terbuka agar menciptakan suasana kerja yang harmonis sehingga menghasilkan dampak yang positif bagi perusahaan.
Dimensi kebutuhan akan afiliasi dengan indikator rasa kebanggaan dalam mengerjakan semua tugas tanpa harus takut gagal memperoleh nilai 3,66 dengan kriteria baik. Meskipun pegawai sudah melaksanakan tugasnya dengan baik tanpa harus takut gagal namun nilai yang diperoleh jauh dari nilai rata-rata keseluruhan indikator, dan cara mengatasinya yaitu pimpinan harus mampu memberikan apresiasi kepada pegawai yang telah menjalankan tugas dengan baik tanpa harus takut gagal agar mendorong pegawai lebih berani lagi mengerjakan segala sesuatunya tanpa harus takut gagal..

Dalam hal ini dapat dilihat bahwa motivasi pegawai pada Badan Narkotika Nasional Kota Pematangsiantar sudah dikategorikan baik. Walaupun sudah dikategorikan baik, instansi juga perlu memberikan motivasi yang membuat pegawai merasa puas terhadap motivasi yang diberikan pimpinan sehingga mereka mampu mengkondisikan kerja sama yang baik antar pegawai sehingga menimbulkan rasa kebanggaan yang timbul dari diri pegawai masing-masing tanpa harus takut gagal.

\section{b. Etos kerja Pada Badan Narkotika Nasional} Kota Pematangsiantar

Etos kerja merupakan seperangkat sikap atau pandangan mendasar yang dipegang pegawai untuk menilai bekerja sebagai suatu hal positif bagi peningkatan kualitas kehidupan, sehingga mempengaruhi perilaku kerjanya dalam organisasi. Indikator etos kerja yang ada pada Badan Narkotika Nasional Kota Pematangsiantar yang dikatakan tinggi, dapat dilihat dari hasil kuesioner yang dibagikan kepada responden, dan diperoleh nilai rata-rata 4,00 dengan kriteria jawaban baik. Namun, masih terdapat beberapa indikator yang masih berada di bawah nilai rata-rata, yaitu pada dimensi kerja adalah rahmat dengan indikator pegawai memiliki kepatuhan dalam bekerja diperoleh nilai rata-rata 3,96 dengan kriteria jawaban baik, untuk mengatasinya pegawai harus mampu mengendalikan egonya masing-masing dan benar-benar melaksanakan tugasnya tanpa diperintah berulangulang.

Pada dimensi kerja adlah amanah dengan indikator pegawai memiliki amanah untuk bekerja dengan komitmen diperoleh nilai rata-rata 3,96 dengan kriteria jawaban baik, untuk itu amanah dari pimpinan harus lebih benar dan serius lagi dikerjakan. Pada indikator pegawai memiliki amanah untuk bekerja dengan bertanggung jawab diperoleh dengan nilai rata-rata 3,85 dengan kriteria jawaban baik, untuk itu amanah dari pimpinan harus lebih benar dikerjakan dengan penuhtanggung jawab.dan pada indikator amanah dalam kesungguhan dalam bekerja diperoleh nilai rata-rata 3,37 dengan kriteria jawaban baik, untuk itu benar-benar dikerjakan sesuai kerjanya masing-masing.

Pada dimensi kerja adalah panggilan dengan indikator pegawai memiliki panggilan untuk mau bekerja dengan integritas diperoleh nilai rata-rata 3,85 dengan kriteria jawaban baik. Pada dimensi 
kerja adalah aktualisasi dengan indikator pegawai memiliki aktualisasi untuk mau bekerja tuntas diperoleh nilai rata-rata3,85 dengan kriteria jawaban baik, untuk itu pegawai harus mampu menyelesaikan tugasnya dengan tuntas. Pada dimensi kerja adalah ibadah dengan indikator kerapian dalam bekerja diperoleh nilai rata-rata 3,92 dengan kriteria jawaban baik, untuk itu kerapian pegawai juga harus diperhatikan karena sebagian dari kerapian adalah kenyamanan untuk dapat bekerja dengan baik terutama untuk perusahaan itu sendiri.

Pada dimensi kerja adalah kehormatan dengan indikator pegawai di dalam ketekunan diperoleh nilai rata-rata 3,96 dengan kriteria baik, untuk itu pimpinan juga harus saling menghargai para pegawai untuk menciptakan hubungan yang harmonis. Pada dimensi kerja adalah pelayanan dengan indikator pegawai bekerja dengan rendah hati diperoleh nilai rata-rata 3,85 dengan kriteria jawaban baik, untuk itu pegawai harus mempunyai keyakinan yang kuat untuk mau bekerja dengan penuh kerendahan hati dalam menyelesaikan tugasnya

Dalam hal ini jawaban dari responden mengenai komitmen sudah berada pada kriteria baik. Namun pegawai juga harus menyadari bahwa etos kerja terhadap suatu organisasi merupakan suatu hal yang sangat penting untuk ditanamkan dalam diri pegawai, dengan demikian pegawai dapat sepenuh hati untuk melaksanakan setiap tugas-tugas yang diberikan.

\section{c. Kinerja Pegawai Pada Badan Narkotika \\ Nasional Kota Pematangsiantar}

Kinerja merupakan salah satu faktor penting yang menjadi tolak ukur bagi sebuah organisasi untuk mencapai tujuannya. Apabila kinerja pegawai dalam sebuah instansi sudah baik, maka tujuan instansi dapat dengan mudah tercapai. Indikator kinerja pegawai pada Badan Narkotika Nasional Kota Pematangsiantar sudah dalam kategori baik. Hal ini dapat dilihat dari jawaban responden dengan nilai keseluruhan rata-rata sebesar 3,90 dengan kriteria jawaban baik. Namun masih terdapat beberapa indikator yang perlu diperhatikan karena nilainya masih di bawah rata-rata, seperti pada dimensi sasaran kerja pegawai dengan indikator menangani volume pekerjaan yang cukup banyak memperoleh nilai rata-rata sebesar 3,78 dengan kriteria jawaban baik. Cara untuk meningkatkannya adalah memberikan dukungan dan perhatian khusus kepada setiap pegawai yang bekerja lembur agar tetap senantiasa memiliki semangat dalam menyelesaikan pekerjaannya.

Pada indikator tingkat ketelitian pegawai dalam meyelesaikan pekerjaan memperoleh nilai sebesar 3,74 dengan kriteria jawaban baik. Cara meningkatkannya adalah pegawai harus lebih memperhatikan detail setiap pekerjaan yang dilakukan untuk memperoleh hasil yang baik. Pada indikator tingkat efisien waktu yang dipergunakan dalam menyelesaikan pekerjaan diperoleh nilai ratarata sebesar 3,33 dengan kriteria jawaban cukup baik dan pada indikator ketepatan waktu dalam menyelesaikan tugas diperoleh nilai rata-rata sebesar 3,37 dengan kriteria jawaban cukup baik. Cara meningkatkannya adalah memotivasi dan mengarahkan pegawai agar mampu memanfaatkan waktu bekerja sebaik mungkin untuk mencapai sasaran kerja sesuai dengan target yang telah ditentukan.

Pada dimensi perilaku kerja dengan loyalitas pegawai bekerja dalam instansi memperoleh nilai rata-rata sebesar 3,74 dengan kriteria jawaban baik. Cara meningkatkannya adalah dengan selalu melibatkan pegawai dalam setiap kegiatan yang diadakan oleh instansi. Pada indikator kepatuhan pegawai dalam menaati peraturan perundangundangan yang ditetapkan instansi memperoleh nilai rata-rata sebesar 3,37 dengan kriteria jawaban cukup baik. Cara meningkatkannya adalah memberikan kesadaran penuh pada pegawai untuk senantiasa menaati peraturan yang berlaku dan bertindak tegas dalam memberikan sanksi terhadap pegawai yang melakukan pelanggaran atau kesalahan.

Pada indikator kemampuan pimpinan dalam memotivasi bawahannya memperoleh nilai rata-rata sebesar 3,70 dengan kriteria jawaban baik. Cara meningkatkannya adalah sebaiknya pimpinan memberikan dukungan dan motivasi baik secara lisan maupun teladan sehingga dapat membangkitkan semangat pegawai dalam bekerja. Selanjutnya pada indikator kemampuan pimpinan dalam mengarahkan seluruh bawahannya memperoleh nilai rata-rata sebesar 3,74 dengan kriteria jawaban baik. Cara meningkatkannya adalah sebaiknya pimpinan melakukan pendekatan dengan seluruh bawahannya agar terjalin kerjasama yang baik dalam instansi.

Kinerja pegawai pada Badan Narkotika Nasional Kota Pematangsiantar dalam hal ini sudah dikategorikan baik. Namun, walaupun demikian sebaiknya pimpinan harus berusaha menjalin hubungan yang dekat dengan seluruh pegawai dan memberikan pembinaan secara formal dengan cara memotivasi pegawai agar dapat bekerja dengan lebih baik lagi.

\section{KESIMPULAN DAN SARAN}

\section{Kesimpulan}

a. Hasil analisis regresi linear berganda diperoleh nilai $\hat{\mathrm{Y}}=6,518+0,827 \mathrm{X}_{1}+0,314 \mathrm{X}_{2}$, artinya terdapat pengaruh yang positif antara motivasi $\left(\mathrm{X}_{1}\right)$ dan etos kerja $\left(\mathrm{X}_{2}\right)$ terhadap kinerja pegawai (Y) pada Badan Narkotika Nasional Kota Pematangsiantar.

b. Hasil analisis korelasi (r) sebesar 0,791 yang artinya terdapat hubungan yang kuat dan positif antara motivasi dan etos kerja terhadap kinerja pegawai pada Badan Narkotika Nasional Kota Pematangsiantar. Kemudian diperoleh nilai koefisien determinasi (R Square) $=0,625$, artinya baik tidaknya kinerja pegawai (Y) pada Badan Narkotika Nasional Kota Pematangsiantar sebesar $62,5 \%$ dapat dijelaskan oleh motivasi $\left(\mathrm{X}_{1}\right)$ dan etos kerja $\left(\mathrm{X}_{2}\right)$, sedangkan sisanya sebesar $37,5 \%$ dipengaruhi oleh faktor lain yang 
tidak dijelaskan dalam penelitian ini seperti dukungan organisasi, dukungan manajemen, lingkungan kerja, budaya organisasi, efektivitas dan efisiensi, disiplin dan sebagainya.

c. Hasil pengujian hipotesis secara simultan dengan uji $\mathrm{F}$, diperoleh nilai $\mathrm{F}_{\text {hitung }}$ sebesar 20,263 $>\mathrm{F}_{\text {tabel }}$ dengan $(0,05 ; 2$ vs 24$)$ sebesar 3,40 atau dengan signifikan $0,000<\mathrm{a} 0,05$, maka $\mathrm{H}_{0}$ ditolak, artinya motivasi dan etos kerja berpengaruh positif dan signifikan terhadap kinerja pegawai pada Badan Narkotika Nasional Kota Pematangsiantar.

d. Hasil pengujian hipotesis secara parsial dengan uji $t$, diperoleh nilai $t_{\text {hitung }}$ pada variabel $X_{1}$ (motivasi) sebesar 2,577 $>$ dari $t_{\text {tabel }}$ dengan $\mathrm{dk}=$ n-k-1 (27-2-1=24) sebesar 2,063 atau taraf signifikan $0,017<$ a 0,05 , maka $\mathrm{H}_{0}$ ditolak, artinya motivasi berpengaruh positif dan signifikan terhadap kinerja pegawai pada Badan Narkotika Nasional Kota Pematangsiantar. Kemudian nilai $t_{\text {hitung }}$ pada variabel $\mathrm{X}_{2}$ (etos kerja) sebesar 2,807 $>$ dari $t_{\text {tabel }}$ dengan $d f=n-k-$ $1,(27-2-1=24)$ sebesar 2,224 atau taraf signifikan $0,036<$ a 0,05 , maka $\mathrm{H}_{0}$ ditolak, artinya etos kerja berpengaruh positif dan signifikan terhadap kinerja pegawai pada Badan Narkotika Nasional Kota Pematangsiantar.

\section{Saran}

a. Untuk mengoptimalkan upaya motivasi, perusahaan lebih sering memberikan motivasi bagi pegawai sehingga dapat bekerja dengan baik dan merasa puas dalam pekerjaannya dan dapat bekerja dengan sukarela dan tetap mengabdi pada perusahaan

b. Untuk meningkatkan etos kerja pada Badan Narkotika Nasional Kota Pematangsiantar masih ada beberapa indikator yang belum optimal, untuk itu instansi harus mampu meningkatkan etos kerja bagi pegawainya dengan lebih memperkuat kerja dengan rahmat, amanah, panggilan, aktualisasi dan ibadah. Untuk itu pimpinan sebaiknya harus lebih memperhatikan setiap pegawai agar dapat bekerja dengan penuh tanggung jawab dan sungguh-sungguh sesuai dengan amanha yang telah diberikan.

Kinerja pegawai pada Badan Narkotika Nasional Kota Pematangsiantar masih perlu ditingkatkan karena masih ada indikator yang belum optimal yaitu pada dimensi sasaran kerja pegawai dengan indikator waktu. Untuk mengoptimalkannya, maka perlu dilakukan peningkatan hasil kerja agar lebih baik lagi, yaitu dengan cara memberikan motivasi dan arahan kepada setiap pegawai agar dapat memanfaatkan waktu bekerja dengan sebaik mungkin agar sehingga dapat menyelesaikan pekerjaanya dengan tepat waktu.

E. Kinerja pegawai pada Badan Narkotika Nasional Kota Pematangsiantar masih perlu ditingkatkan karena masih ada indikator yang belum optimal yaitu pada dimensi sasaran kerja pegawai dengan indikator waktu. Untuk mengoptimalkannya, maka perlu diberikan arahan kepada setiap pegawai agar dapat memanfaatkan waktu bekerja dengan sebaik mungkin sehingga dapat menyelesaikan pekerjaanya dengan tepat waktu.

\section{F. DAFTAR PUSTAKA}

Anoraga, Panji. 2001. Psikologi Kerja. Jakarta: PT Rineka Cipta.

Bangun, Wilson. 2012. Manajemen Sumber Daya Manusia. Penerbit Erlangga.

Cherrington. 2000. Manajemen. Edisi Kedua, Cetakan Kedelapanbelas. Bogor: Grafika Mardi Yuana.

Daft, Richard L. 2002. Manajemen. Jilid 1. Jakarta: Penerbit Erlangga.

Griffin, Ricky W. 2004. Manajemen. Jilid 1. Edisi 7. Jakarta: Erlangga.

Handoko, T. Hani. 2002. Manajemen Personalia dan Sumber Daya Manusia. Yogyakarta: BPFE.

Luthans, Fred. 2006. Perilaku Organisasi. Edisi 10. Yogyakarta: ANDI.

Mangkunegara, Anwar Prabu. 2005. Manajemen Sumber Daya Manusia Untuk Perusahaan. Bandung: PT. Remaja Rosdakarya.

........., A. Prabu, 2015. Manajemen Sumber Daya Manusia Perusahaan. Bandung: PT Remaja Rosdakarya.

Mathis, Robert L. dan John H. Jackson, 2006. Human Resources Management. Edisi 10. Jakarta: Salemba Empat.

Mondy, Wayne R. 2008. Manajemen Sumber Daya Manusia. Jilid 1. Edisi Kesepuluh. Jakarta: Erlangga.

Peraturan Pemerintah Republik Indonesia Nomor 46 Tahun 2011. Tentang Penilaian Prestasi Kerja Pegawai Negeri Sipil.

Rivai, Veithzal. 2004. Manajemen Sumber Daya Manusia Untuk Perusahaan dari Teori ke Praktik. Cetakan Pertama, Jakarta: PT. Raja Grafindo Persada.

Robbins, Stephen P. dan Timothy A. Judge. 2006. Manajemen. Edisi 11. Jakarta: Salemba Empat.

Sinamo, Jansen. 2005 . Delapan Etos Kerja Profesional: Navigator Anda Menuju Sukses. Bogor : Grafika Mardi Yuana 